УДК 330.34

DOI: https://doi.org/10.54929/pmtl-issue1-2021-15

\title{
НЕОБХІДНІСТЬ ІНСТИТУЦІЙНО-УПРАВЛІНСЬКИХ ТА ІНСТИТУЦІЙНО-ПРАВОВИХ ЗМІН В СФЕРІ УПРАВЛІННЯ ПУБЛІЧНИМИ ПРОЄКТАМИ ТА ПРОГРАМАМИ
}

\author{
THE NEED FOR INSTITUTIONAL AND MANAGERIAL CHANGES \\ AND INSTITUTIONAL AND LEGAL CHANGES IN THE SPHERE \\ OF MANAGEMENT OF PUBLIC PROJECTS AND PROGRAMS
}

Старченко Г. В.

доктор економічних наук, доцент, професор кафредри публічного управління та менеджменту організацій,

Національний університет «Чернігівська політехніка»

ORCID: 0000-0003-2707-1055

Grygoriy Starchenko

Doctor of Economics, Associate Professor,

Professor of Department of Public Administration and Organizations' Management,

Chernihiv Polytechnic National University

В статті зазначено, що швидкий розвиток інформаційних технологій під впливом глобалізаційних процесів призводить до необхідності зміни вектору розвитку сфери публічного управління України та вимагає впровадження інституційно-управлінських та інституційно-правових змін в сфрері управління публічними проєктами та програмами через трансфер інновацій у сферу публічного управління. Необхідність зміни вектору розвитку сфрери публічного управління повинно відбуватися через фрормування відповідного інституційного та організаційного забезпечення, а саме через наявність адекватного ринкового середовища, законодавчого та організаційного забезпечення, інноваційної інфраструктури, відповідних проєктно-орієнтованих управлінських структур, а також шляхом встановлення ефективної колаборації між освітою, наукою, бізнесом, державою та іншими суспільними інститутами. Підкреслено, що від стану та особливостей інституційного та організаційного забезпечення проєктно-орієнтованого управління публічною сфрерою у великій мірі залежить адаптивність, керованість та ефективність їі розвитку, а також їі ресурсний, структурний та часовий виміри. Наголошено, що система інституційного забезпечення проєктно-орієнтованого управління розвитком публічної сфери повинна розглядатись як відкрита та динамічна система, яка реагує на вплив зовнішнього глобального простору, наприклад, міжнародних інституцій та внутрішніх чинників державного розвитку. Особливе місце в системі інституційного забезпечення проєктно-орієнтованого управління розвитком публічної сфрери доцільно відвести синергетичному зв'язку, який при спільних діях незалежних проєктно-орієнтованих суб'єктів економіки. Ключові слова: публічне управління, публічна сфера, проєктно-орієнтоване управління, інноваційний розвиток публічної сорери, інституційно-управлінські зміни, інституційно-правові зміни, проєкти та програми в публічній сорері.

В статье отмечено, что быстрое развитие информационных технологий под влиянием глобализационных процессов приводит к необходимости изменения вектора развития сфреры публичного управления Украины и требует внедрения институционно-управленческих и институционально правовых изменений в сфрере управления публичными проектами и программами через трансфер инноваций в сферу публичного управления. Необходимость изменения вектора развития сфреры публичного управления должна обусловлена формированием соответствующего институционального и организационного обеспечения, а именно через наличие адекватной рыночной среды, законодательного и организационного обеспечения, инновационной инфраструктуры, соответствующих проектно-ориентированных управленческих структур, а также путем установления эфффективной коллаборации между образованием, наукой, бизнесом, государством и другими общественными институтами. Подчеркнуто, что от состояния и особенностей институционального и организационного обеспечения проектно-ориентированного управления публичной сферой в большой степени зависит адаптивность, управляемость и эфрфективность ее развития, а также ресурсное, структурное и временное измерения. Отмечено, что система институционального обеспечения проектно-ориентированного управления развитием публичной сфреры должна рассматриваться как открытая и динамичная система, реагирующая на влияние внешнего глобального пространства, например, международных институций и внутренних фракторов государственного развития. Особое место в системе институционального обеспечения проектно-ориентированного управления развитием публичной сферы целесообразно отвести синергетической свя- 
зи, которая при совместных действиях независимых проектно-ориентированных субъектов экономики. Ключевые слова: публичное управление, публичная сфрера, проектно-ориентированное управление, инновационное развитие публичной сфреры, институционно-управленческие изменения, институционно-правовые изменения, проекты и программы в публичной сфрере.

The article notes that the rapid development of information technologies under the influence of globalization processes leads to the need to change the vector of development of the sphere of public administration in Ukraine and requires the introduction of institutional, managerial and institutional legal changes in the field of managing public projects and programs through the transfer of innovations to the sphere of public administration. The need to change the vector of development of the sphere of public administration should occur through the formation of appropriate institutional and organizational support, namely through the presence of an adequate market environment, legislative and organizational support, innovative infrastructure, appropriate project-oriented management structures, as well as by establishing effective collaboration between education, science, business, the state and other public institutions. It is emphasized that the adaptability, manageability and efficiency of its development, as well as resource, structural and temporal dimensions, largely depend on the state and features of the institutional and organizational support for project-oriented management of the public sphere. It is noted that the system of institutional support for project-oriented management of the development of the public sphere should be considered as an open and dynamic system that responds to the influence of the external global space, for example, international institutions and internal factors of state development. It is advisable to assign a special place in the system of institutional support for project-oriented management of the development of the public sphere to synergistic communication, which is the joint action of independent project-oriented economic entities. The institutional and organizational support for the development of the public sphere that has been formed today is fragmented and ineffective, which is manifested in the absence of a single legislative interpretation of the innovative development of the public sphere, duplication of powers of authorities, insufficient coherence and coordination of the activities of executive authorities, and the absence of clear criteria. for the implementation of projects in the public sphere. Key words: public administration, public sphere, project-oriented management, innovative development of the public sphere, institutional and managerial changes, institutional and legal changes, projects and programs in the public sphere.

Постановка проблеми у загальному вигляді та їі зв'язок із важливими науковими чи практичними завданнями. Швидкий розвиток інформаційних технологій під впливом глобалізаційних процесів призводить до необхідності зміни вектору розвитку сфери публічного управління України та вимагає впровадження інституційноуправлінських та інституційно-правових змін в сорері управління публічними проєктами та програмами. Безумовно, об'єктивною реальністю стала глобалізація головним фрактором розвитку якої $€$ досягнення науково-технічного прогресу. Глобалізаційні процеси швидко та якісно змінюють конфрігурацію глобальної економічної системи. Інтеграція національної економіки України в глобальну економічну систему призводить до суттєвих змін в усіх сфрерах соціально-економічної життєдіяльності, включаючи публічну сфреру. Завдяки сучасним інформаційним технологіям прискорюється розвиток і трансфер інновацій у сореру публічного управління. Сучасні тенденції розгортання світових інноваційних процесів підтверджують важливість переосмислення підходів до формування драйверів подальшого розвитку сорери публічного управління, що являє собою область, у межах якої реалізуються відносини між громадянським суспільством як системою здебільшого горизонтально вибудуваних структур, які слугують для фрормування та захисту групових інтересів, і політичною владою, ії̈ юридичними, силовими й адміністративними інститутами.

Практика провідних країн світу доводить, що зміна вектору розвитку сфери публічного управління повинна відбуватися через формування відповідного інституційного та організаційного забезпечення, а саме наявності адекватного ринкового середовища, законодавчого та організаційного забезпечення, інноваційної інфрраструктури, відповідних проєктно-орієнтованих управлінських структур, а також шляхом встановлення ефективної колаборації між освітою, наукою, бізнесом, державою та іншими суспільними інститутами.

В свою чергу, інститути скеровують у певне русло взаємодію суб'єктів економіки та визначають вектор руху суспільства, стимулюючи до розвитку сфреру публічного управління. Отже, орієнтація на інноваційний шлях розвитку національної економіки та публічної сфрери потребує певних інституційно-управлінських та інституційноправових змін в сорері управління публічними проєктами та програмами.

Аналіз останніх досліджень і публікацій, в яких започатковано розв'язання даної проблеми і на які спирається автор. Розвиток публічної сфери в Україні потребує залучення до цього процесу сучасного інструментарію, успішного досвіду передових країн, а також додаткових фрінансових ресурсів. Основним інструментом залучення небюджетних коштів для розвитку $\epsilon$ проєкти і програми. Сучасну методологію проєктного менеджменту необхідно впроваджувати в усі сорери життя держави, і в першу чергу, в публічну сфреру. Отже, основна роль в модернізації ссрери публічного управління належить проєктній 


\section{діяльності.}

Сучасна методологія проєктно-орієнтованого управління викладена в працях закордонних та вітчизняних дослідників, зокрема таких: Р. Арчибальд, В. Бурков, Н. Бушуєва, С. Бушуєв, В. Вайсман, О. Возний, Д. ДеКарло, К. Кошкін, І. Мазур, В. Молоканова, П. Мартин, С. Рижков, Х. Танака, К. Тейт, Дж. Тернер, Ю. Тесля, А. Товб, Г. Ципес, В. Шапіро, Ф. Ярошенко та інших.

Віддаючи належне науковим здобуткам зазначених учених, треба зауважити, що подальшого наукового обґрунтування вимагає питання необхідності впровадження інституційно-управлінських та інституційно-правових змін в сфері управління публічними проєктами та програмами.

Виділення невирішених раніше частин загальної проблеми, котрим присвячується означена стаття. Занизький рівень розвитку сфери публічного управління на тлі євроінтеграційних прагнень країни визначають важливість зміни підходів до управління в публічній сфрері. Вирішення такої проблеми стає пріоритетом розвитку країни, що потребує фрормування відповідного механізму реалізації інституційно-управлінських та інституційно-правових змін в сфері управління публічними проєктами та програмами. У цьому контексті вагомого значення набуває необхідність поєднання проєктно-орієнтованого управління із загальним перебігом процесів публічного управління з метою набуття державною сферою ознак надійності та ефрективності функціонування ії основних інститутів за ресурсних обмежень. Тим самим застосування проєктно-орієнтованого управління в публічній сфрері дає змогу поширити методологію проєктного менеджменту задля сполучення інтересів інститутів влади і структур громадянського суспільства, які відбуваються в багатьох галузях суспільного життя: соціальноекономічній, громадянсько-правовій, політичній.

Формулювання цілей статті (постановка завдання). Метою даної статті $€$ обґрунтування необхідності впровадження інституційноуправлінських та інституційно-правових змін в сфері управління публічними проєктами та програмами через процеси інституалізації у програмно-цільовий формат способів втручання державних органів влади чи органів місцевого самоврядування у соціальну дійсність з метою розв'язання публічної проблеми.

Виклад основного матеріалу дослідження. Під проєктом у публічній сфері розуміють комплекс взаємопов'язаних логічно-структурованих завдань і заходів, упорядкованих у масштабі часу, які спрямовані на розв'язання найважливіших проблем розвитку держави, окремих галузей економіки, адміністративно-територіальних одиниць чи територіальних громад, організацій та установ і здійснюються в умовах фрінансових та інших ре- сурсних обмежень у визначені терміни $[4$, с. 86].

Особливістю проєктів у публічній сфері $€$ розв'язання проблем, які винесені на урядовий порядок денний та формалізовані (описані) у відповідних урядових документах - урядовій програмі, концепціях чи стратегіях у формі стратегічних пріоритетів чи завдань. Це має першочергове значення для розробки програм і проєктів, оскільки головною підставою для розробки програм/проєктів у публічній сфрері $є$ наявність проблеми, яка мусить бути зафріксована та легко перевірятися через засоби електронного зв язку. Проєкти можуть реалізовуватись одноосібно або ж у кооперації з партнерами. Сукупність проєктів складає програму або портфрель проєктів [1].

Управління проєктами в публічній сфері це процес інституалізації у програмно-цільовий формат способів втручання державних органів влади чи органів місцевого самоврядування у соціальну дійсність з метою розв'язання публічної проблеми [4, с. 87].

Інституційні умови підвищення конкурентоспроможності національної економіки під впливом синергетичних детермінант проєктно-орієнтованого управління інноваційним розвитком слід розглядати як сукупність необхідних інститутів, які прямо або опосередковано сприяють активізації процесів інноваційного розвитку в економіці. Проєктноорієнтоване управління розвитком публічної сорери не можливе без інституційно-управлінських та інституційно-правових змін.

Інституційно-управлінські зміни - це необхідні зміни у державній інституційній підсистемі, а саме, в органах публічної сфрери (оптимізація системи управління; вдосконалення системи регіонального та місцевого публічного управління та адміністрування).

Інституційно-правові зміни - забезпечують створення нормативно-правових умов, які стимулюють розвиток публічної сфери (систематизація та вдосконалення законодавства у сферах державного управління; розробка та реалізація програм та проєктів в публічній сфрері: соціальних, правових, економічних, політичних).

Від стану та особливостей інституційного та організаційного забезпечення проєктноорієнтованого управління публічною сферою у великій мірі залежить адаптивність, керованість та ефрективність ії розвитку, а також ії ресурсний, структурний та часовий виміри.

Інституційне забезпечення є сукупністю інститутів та інституцій, нормативно-правових актів, що забезпечують наявність організаційних, економічних та інших умов розвитку публічної сфрери.

Інституційне забезпечення проєктноорієнтованого управління публічною сферою слід розглядати як складну за структурою систему, що об'єднує підсистеми, які орієнтовані на різні кри- 
терії цілей розвитку публічної сорери: підвищення рівня стандартів і якості життя; зниження ресурсомісткості національної економіки у всіх її секторах; підвищення конкурентоспроможності економіки з урахуванням викликів глобального інноваційного простору та інституцій що їх забезпечують; покращення збалансованості розвитку регіонів. Такій системі, згідно з теорією систем, має бути притаманна головна ціль, яка полягає в досягненні бажаного стану інституційного середовища згідно стратегії інноваційного розвитку, який би зменшував витрати проєктно-орієнтованих суб'єктів економіки при здійсненні інноваційної діяльності та формуванні оптимальної структури економіки.

Система інституційного забезпечення проєктноорієнтованого управління розвитком публічної сфрери повинна розглядатись як відкрита та динамічна система, яка реагує на вплив зовнішнього глобального простору, наприклад, міжнародних інституцій та внутрішніх чинників державного розвитку. Доцільно виділити типи зв'язків, які повинні існувати між елементами такої системи:

- зв'язки взаємодії та координації між інституціями, що визначаються стратегічними орієнтирами розвитку публічної сфери;

- структурні зв'язки побудови - передбачають, що наявність одних елементів підсистеми визначає необхідність наявності інших, наприклад, стратегія розвитку публічної сфери передбачає розбудову таких інститутів, як стандарти управління проєктами в публічній сфрері;

- зв'язки функціонування - різні проєктноорієнтовані суб'єкти економіки системи інституційного середовища розвитку публічної сфери забезпечують ефективну колаборацію між собою;

- зв'язки розвитку - ефективна колаборація проєктно-орієнтованих суб'єктів економіки забезпечує зміну стану об'єкта інституційного впливу.

Особливе місце в системі інституційного забезпечення проєктно-орієнтованого управління розвитком публічної сфери доцільно відвести синергетичному зв'язку, який при спільних діях незалежних проєктно-орієнтованих суб'єктів економіки може забезпечити зростання до більшого значення загального ефекту, ніж сума ефректів цих суб'єктів, якщо вони б діяли незалежно.

На кінець 2018 року законодавство, що регулює інноваційну діяльність в Україні включає майже 200 різноманітних нормативно-правових актів: більше 10 законодавчих актів, понад 50 нормативно-правових актів Уряду, близько 100 різноманітних відомчих документів тощо. Основними нормативно-правовими актами, що регулюють інноваційну діяльність на макрорівні є: Закони України «Про інноваційну діяльність», «Про інвестиційну діяльність», «Про наукову і науково-технічну діяльність», «Про наукову і науково-технічну експертизу», «Про спеціальний режим інноваційної діяльності технологічних парків», «Про пріоритетні напрями інноваційної діяльності в Україні», «Про наукові парки», «Про державне регулювання діяльності у сфрері трансферу технологій», «Про фінансову підтримку інноваційної діяльності підприємств, що мають стратегічне значення для економіки та безпеки держави» та ін.; розпорядження та постанови Кабінету Міністрів України «Про концепцію розвитку національної інноваційної системи», «Про затвердження плану заходів з реалізації Концепції реформування державної політики в інноваційній сфрері на 2015-2019 роки», Закони про охорону інтелектуальної власності, та інші нормативно-правові акти, що регулюють суспільні відносини у сфері інновацій та інноваційного розвитку [3].

Слід зауважити, що більшість нормативноправових актів, що регламентують інноваційну діяльність в Україні на макрорівні, були прийняті у 90-х роках минулого століття та на початку нинішнього, тому більшість таких нормативноправових актів потребують перегляду та уточнення відповідно до вимог Міжнародних стандартів та керівництв, міжнародних інституцій глобального інноваційного простору. Потребує уточнення дефрініції «інновація», «інноваційне підприємство», «інноваційна інфрраструктура», відповідно до Керівництва Осло (2018р.), Керівництва Фраскаті (2015 р.) та Керівництва Канберри та ін [2].

Недосконалість законодавства в сфері інноваційного розвитку, позначається на інституційній системі публічної сфрери, що здійснює управління цими процесами, а також обумовлена ії діяльністю. Завданнями інноваційного розвитку у різні часи займалися Державний комітет України з питань науки, інновацій та інформатизації, Державний комітет України з питань науково-технічного та інноваційного розвитку, Державне агентство України з інвестицій та інновацій, яке було перейменовано у Державне агентство України з інвестицій та розвитку, Державне агентство з інвестицій та управління національними проєктами України та ін.

На даний момент в Україні відсутня будь-який інститут, який би повністю відповідав за інноваційний розвиток та реалізацію національних проєктів публічної сфрери. Система інституцій, що мають здійснювати державне управління інноваційним розвитком публічної сфрери сьогодні, включає Президента, Верховну раду, обласні та районні ради, представницькі органи місцевого самоврядування, Кабінет Міністрів України, Міністерство освіти і науки України, Міністерство розвитку економіки, торгівлі та сільського господарства, Національну раду з питань розвитку науки і технологій. Слід відзначити, що компетенції обласних та районних рад, представницьких органів місцевого самоврядування щодо забезпечення інноваційного 
розвитку економіки, чітко не окреслені.

Тобто, усю сукупність інституцій, що здійснюють державне регулювання діяльності щодо розвитку публічної сфери можна умовно розділити на дві групи: ті, що здійснюють пряме управління; ті, що здійснюють опосередковане управління. До першої групи відносяться: Кабінет Міністрів України, У т.ч. Міністерство освіти і науки України, Міністерство розвитку економіки, торгівлі та сільського господарства, Національна рада з питань розвитку науки і технологій, відповідні структурні підрозділи обласних та районних рад, представницькі органи місцевого самоврядування; до другої-Президент, Верховна Рада [2].

Висновки. Незважаючи на велику кількість нормативно-правових актів, а також інституцій, що на даний момент здійснюють управління розвит- ком публічної сфери, сформоване сьогодні інституційне та організаційне забезпечення такого розвитку є фрагментарним та неефективним, що знаходить прояв у відсутності єдиного законодавчого тлумачення інноваційного розвитку публічної сфрери, дублюванні повноважень органів влади, недостатній узгодженості та координації діяльності органів виконавчої влади, відсутності чітких критерії диференціації та надання державної підтримки щодо реалізації проєктів в публічній сфері. Це обумовлює негативні тенденції які позначаються на стані та особливостях розвитку економіки України, публічної сфери, що фріксується погіршенням критеріїв синергетичних детермінант проєктно-орієнтованого управління розвитком публічної сорери [5].

\section{БІБЛІОГРАФІЧНИЙ СПИСОК:}

1. Безверхнюк Т. М., Котова Н. О., Попов С. А. Управління проектами в публічній сфері: навч. посібн. За заг. ред. Безверхнюк Т. М. Одеса: ОРІДУ НАДУ, 2011. 295 с.

2. Бочарова Ю. Г. Розвиток інноваційної інфраструктури національної економіки: теорія і практика : дис. ... д-ра ек. наук : 08.00.03, Вищий навчальний заклад «Університет імені Альфреда. Дніпро. 2019. 530 с.

3. Офріційний вебпортал парламенту України. Законодавство України. URL: https://zakon.rada.gov.ua/laws (дата звернення: 10.09.2021).

4. Старченко Г. В. Проактивне управління проектами в публічній сфрері. Публічне адміністрування: наукові дослідження та розвиток: електронний науковий журнал. 2017. 2(4). С. 84-91.

5. Старченко Г. В. Проектно-орієнтоване управління інноваційним розвитком національної економіки: теорія, методологія та практика: монографія. Київ, 2019. 326 с.

\section{REFERENCES:}

1. Bezverkhniuk, T. M., Kotova, N. O., \& Popov, S. A. (2011). Upravlinnia proektamy v publichnii sferi: navch. posibn. Za zah. red. Bezverkhniuk T. M. [Project management in the public sphere: textbook. manual For the head. ed. Bezverkhnyuk T. M.]. Odesa: ORIDU NADU [in Ukrainian].

2. Bocharova, Yu. H. (2019). Rozvytok innovatsiinoi infrastruktury natsionalnoi ekonomiky: teoriia i praktyka. [Development of innovation infrastructure of the national economy: theory and practice]. Doctor's thesis. Vyshchyi navchalnyi zaklad «Universytet imeni Alfreda, Dnipro [in Ukrainian].

3. Ofitsiinyi vebportal parlamentu Ukrainy. Zakonodavstvo Ukrainy. [Official web portal of the Parliament of Ukraine. Legislation of Ukraine]. Retrieved from https://zakon.rada.gov.ua/laws

4. Starchenko, G. V. (2017). Proaktyvne upravlinnia proektamy v publichnii sferi. [Proactive project management in the public spher]. Publichne Administruvannia: Naukovi Doslidzhennia Ta Rozvytok: Elektronnyi Naukovyi Zhurnal - Public Administration: Research and Development: Electronic Scientific Journal, 2(4), 84-91 [in Ukrainian].

5. Starchenko, G. V. (2019). Proektno-oriientovane upravlinnia innovatsiinym rozvytkom natsionalnoi ekonomiky: teoriia, metodolohiia ta praktyka: monohrafiia. [Project-oriented management of innovative development of the national economy: theory, methodology and practice: monograph]. Kyiv [in Ukrainian]. 